\title{
EU development cooperation: from model to symbol?
}

\author{
Karin Arts and Anna K. Dickson
}

At the beginning of the twenty-first century, the European Union (EU) stands out as an important regional organisation. It entertains formalised relations with almost all other (groups of) states. Although much of its attention is devoted to internal integration, obviously the European Union cannot and does not wish to be an isolated entity. Instead it has expressed the desire and ambition to take up a prominent place in the working of international relations. In addition to the general goal of forging good relations with (potential) political and economic partners across the globe, the Union also wishes to use its place in international relations as a vehicle for advocating some of the values it considers important. Among these values are democracy, social welfare, human rights and liberalism.

The EU perceives development cooperation policy as an important tool to serve both missions. Accordingly, an impressive and unique record of development cooperation activities and of structural and comprehensive policy has been built over time. Until the 1990s, the African, Caribbean and Pacific (ACP) states unequivocally were Europe's most preferred developing country partners, and ACP-EU relations were the most visible and important component of the EU development cooperation programme. ACP-EU relations started at the very creation of the European Economic Community in 1957 and were elaborated first in the Yaoundé and then in the Lomé Conventions and the 2000 Cotonou Agreement. In many peoples' eyes the Lomé Convention came to symbolise EU development cooperation, more so than any other agreement (Grilli, 1993). It linked the EU with a large group of developing countries, many among the poorest, in an innovative agreement which declared itself to operate on the basis of equality of partners. In the 1970s the Lomé Convention was held up as a model for the future of North-South relations in general and EU development policy in particular. The Convention embodied many novel features which seemed to suggest that the EU was prepared to buck the trend in international development and take on board some of the arguments

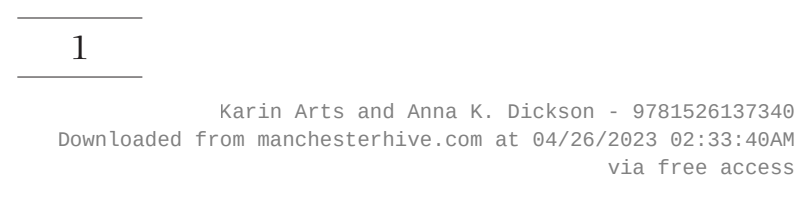


put forward by the Third World in its quest for a New International Economic Order (NIEO). Examples include the contractual approach, the non-reciprocal trade preferences extended by the EU to the ACP countries and the creation of a semi-automatic system of financial compensation for unstable export earnings from agricultural commodities and mining products, the so-called Stabex and Sysmin mechanisms (Arts, 2000: 127-34).

The high hopes engendered by the Lomé Convention have not been realised. Lomé has not been replicated, and its mixed results have initiated a process of rethinking the concepts underlying $\mathrm{ACP}-\mathrm{EU}$ relations and the instruments available to shape them. As a result, the most recent ACP-EU general cooperation treaty - the Cotonou Agreement of June 2000 - breaks rather drastically with the Lomé past, both in terms of content and approach. It introduces greater differentiation in the packages of benefits offered to ACP countries, to be decided on the basis of need and merit. Moreover, many of the unique preferential trade aspects of the past will disappear for all but the least developed. ACP-EU relations clearly are no longer the automatic centrepiece they used to be.

For a long time there were no real incentives to change EU development policy and activities. The external Cold War context did not, in its stability, predispose the EU to make radical changes to development policy. Internal influencing factors were either non-existent or too weak to exert real pressure. After the end of the Cold War the scene changed completely as external and internal influencing factors became mutually reinforcing in support of change (see below).

Firstly, since the late 1990s, under the pressure of various simultaneous developments (including the poor results of EU development cooperation efforts thus far and the changed constellation of the world after the end of the Cold War), the Union embarked on a process of evaluation, reconsideration and reform of both the content and organisation of its development cooperation agenda and activities. Secondly, despite the fact that the EU is the largest collective donor, it does not necessarily have proportionate influence in relevant international development fora. EU policies have been largely peripheral in their influence compared with US and Bretton Woods institutions. This dissonance has been significant in the determination of a number of new policies, including the increased use of political conditionality, the desire to create new regional free trade agreements and the new emphasis on conflict resolution. Thirdly, matters such as the enlargement process and the finalisation of Economic and Monetary Union create internal preoccupations that take away political priority and attention from some aspects of the Union's external relations.

As a result of the combination of developments referred to above, EU development cooperation policy has shifted away from making substantive and innovative attempts to contribute to the North-South dialogue, which was the case during the 1970s and 1980s. Instead, since the 1990s EU development 
cooperation policy has appeared to follow global trends much more than before and is at risk of perpetuating an ineffective agenda. This book contends that, taken as a whole, changes over the period represent a substantive change in the nature of EU development cooperation. That change is characterised as a move from a policy which was, certainly in 1975, unique and held up as a model for the future of North-South relations, to a policy which is neither unique nor successful. More specifically, the contention here is that development cooperation policy in relation to the ACP has become a symbolic gesture from the EU, primarily useful to demonstrate its breadth of commitment to, and relationship with, the South. In so doing it seeks to enhance its perceived role as an important international actor.

Considering these significant changes, it is appropriate and timely to assess the rationale for, and impact of, EU development cooperation so far. That assessment will help us to understand why the Union continues to place so much emphasis on its development cooperation profile, despite the obvious difficulties involved and the modest tangible returns. It will also provide a basis for answering the question of whether the European Union is now moving in the right direction and whether it has the means to realise its ambitions in the realm of development cooperation. These means include political will and the capacity to become what Christopher Hill (1993) termed 'the bridge between the rich and the poor'.

\section{Why EU development policy?}

EU development cooperation is an understudied area of European politics, despite its economic and political significance. Perhaps the European Union does not sufficiently publicise its achievements and failings in this field, or perhaps they appear unimportant compared with the dilemmas of the integration process. Nevertheless, over the years there have been a number of important studies in this area. Ten years ago Grilli (1993), a World Bank economist, published a much cited volume already referred to above, The European Community and the Developing Countries, which examined Europe's relationship with the developing world from a historical, comparative and thematic perspective. Grilli was critical of the ad hoc approach to development which led the EU to have close ties with Africa but not India or China, or even Eastern Europe. For Grilli, development policy seemed to be more the result of chance than of design: 'apart from the top preference reserved for Africa, who got what, when and why among the other developing countries never had a clear and consistent rationale' (1993: 337). It would be difficult to match the breadth of Grilli's study here and we have not tried to do so. Instead we have chosen to isolate those factors which we consider to be the most significant determining factors in the nature of EU development policy.

More recently, in 1997, Marjorie Lister, who has been writing on this topic for many years, published a volume entitled The European Union and the South. 
In this book she argues that Europe could play an important role as champion of the South. From her perspective the long institutional relationship between Europe and most of the developing world, and Africa in particular, makes the Community an ideal partner for, and defender of, the South. Furthermore, this role would provide an appropriate complement to the integration process.

In The European Union and the Third World (2002), Holland seeks to answer the question of whether the EU plays a distinct role in development policy. He does this through an examination of Europe's relationship with different regions and by interrogating the explanatory potential of different integration theories. Like Lister he argues that development policy can enhance the integration process. Like the authors in this volume he recognises that EU development policy is understudied and given only sporadic attention in the European policy-making debates.

There are two recent volumes which look at Europe and the wider world and for which development policy forms one part of this relationship. Brian White's Understanding European Foreign Policy (2001) is specifically concerned with the utility of foreign policy analysis. Bretherton and Vogler (1999), in The European Union as a Global Actor, provide a more detailed and critical account of development policy although their ambit is much wider.

The Commission Green Paper of 1997 declared that the colonial and postcolonial period was behind us and that Europe would be seeking to create a new external environment for its relationship with the developing world. There are a number of articles which specifically address aspects of EU development policy (see, for example, Parfitt, 1996; Watts, 1998; Dickson, 2000; Hurt, 2003). All agree that the post-2000 arrangements represent above all the loss of many of the benefits secured initially in 1975 .

The central question addressed in this book is: why, given the above mentioned circumstances, does the EU still maintain its development policy? That question is justified by an exploration of the manifest changes which have occurred in EU development cooperation policy through the years. This will be done through an analysis of the various external and internal factors that the authors believe have significantly influenced EU development policy, and have directed changes in scope and coverage of that policy. Among the external factors are, firstly, changes in the international environment e.g. the end of the Cold War, the emergence of Central and Eastern Europe, globalisation/ liberalisation (in particular in relation to trade) and increasing civil conflict (ethnic rivalry, failed states). Secondly, other international actors, notably the World Bank, the International Monetary Fund (IMF) and the World Trade Organisation (WTO), and the ideas and concepts they have developed have had an impact on EU policy making in the realm of development. The internal factors considered by this book include, firstly, the changes in the relations between EU member states brought about by the various waves of enlargement. Secondly, there is the influence of the advancing process of European integration. Thirdly, the book looks into the impact of France, as the individ- 
ual member state that historically has influenced European development policy most strongly of all. Fourthly, there are bureaucratic interests of the Commission in keeping up its development profile and activities.

These factors are identified as being key determining factors in the evolution of EU development policy and, it is argued, they explain many of the changes which have taken place over the period. This approach, which differs from other books on the topic, which tend to adopt a historical, regional or policy-making approach, has the advantage of allowing the authors to study in depth one particular factor and apply it more widely to the field of development cooperation. There is no single theoretical approach expounded here although of course we all have our own particular preferences.

The authors of this book contend that, unless the EU recognises and takes account of the factors which have so far determined the parameters of EU development policy, it is unlikely that future policy will have a more significant impact on development.

\section{EU development cooperation: member states' or common policy?}

In practice Europe's relations with the South comprise the bilateral policies of member states plus the collective policies of the Community, at times referred to as a 'mixed system' (Groux and Manin, 1985). The relationship between the two is one of the defining features of EU development cooperation policy in general and of the Lomé Convention/Cotonou Agreement in particular. Development cooperation is a Community policy, although certain member states (the UK and France in particular) have a greater interest in, and influence over, it. Other members of the EU would prefer a more globally oriented policy, notably Austria, the Netherlands, Greece and Germany (Council Ministers, 1997). This debate is not new. Since the 1960s there has been an ongoing discussion about whether development policy should become more globally focused or retain its geographical selectivity based on historical, national rather than Community-wide interests (Faber, 1982; Arts, 2000: 100). The terms of the Cotonou Agreement suggest that internal pressures between the globalists and the regionalists have been decided in favour of the globalists, as the new agreement effectively ends the ACP's status as the EU's most preferred partner. Instead, as is argued in chapter 4, ACP relations are on the way to becoming normalised, that is, they are being brought more in tune with the types of agreement offered to other groups of states. More importantly, the historical basis for support has been deemed less relevant. Instead the EU will offer pro-poor policies targeted at the poorest developing countries (the UN category of least developed countries, LDCs) and other policies more in line with the neoliberal slant for all other developing and transitional economies.

The mixed system can lead to a cumbersome bargaining process in which short-term national goals can prevail over Community values and goals (Edwards and Regelsberger, 1990). Alternatively, member states may sign up 
for Community policies which they have no intention of, or capacity to, implement. This means that what appears to be a united front initially may in practice disintegrate as member states refuse to play by the rules they created themselves (Peterson, 1998).

Different member states' interests also permeate the Commission, particularly at higher levels. Commissioners have to find a balance between Community interests and the European impartiality they are supposed to display, and national allegiances. This is particularly difficult where member states view their appointments in the Commission as representative of the national interest. This balancing game is coupled with the fact that within each DirectorateGeneral (DG) members do not share common nationalities or party loyalties. This set-up makes the establishment of a collective European interest difficult (Middlemas, 1995; Peterson, 1998).

Like many aspects of EU policy making, decisions about development cooperation are often created by compromise - by attempting to get a majority or, if this is not possible, some kind of compromise position. The results are often either watered down solutions or solutions reached at great expense to one or other interested party. A prerequisite for the EU to exercise greater influence in international affairs is to have a common (i.e. coordinated) approach perceptible to outsiders. In his 1993 analysis of the relationship between the EU and the developing world, Grilli argued that there had never been a coherent development policy. Rather there has been a series of ad hoc responses to particular situations: "The sequencing of . . . relations with different groups of developing countries, and of their development cooperation content, appear to have been haphazard, reactive and more dictated by events, and sometimes fashions, than by plans, principles or even a broad strategy' (Grilli, 1993: $337-8$ ).

This is one of the key issues the Commission addressed in its 1992 report, 'Development Policy in the Run Up to 2000' (or 'Horizon 2000'). Here the Commission argued for greater complementarity between, and coordination of, objectives in the development policies of the member states and those of the Community as a means of making development assistance more effective (referred to as 'coordination shortfall'). The report noted a 'gap between the Community's importance as an export market for the developing countries and as a donor of official development assistance on the one hand and its still modest role in the management of the international economic system on the other' (CEC, 1992: 40). The Community as a whole at the time already provided more than half of world aid and, according to the Commission, was well placed to influence the shape of international development policy. However, the report continues, "by not always acting together in these institutions [the IMF and World Bank] the member states and the Community frequently pass the initiative to the US' (CEC 1992: 41).

In 1992 the Treaty on European Union (TEU) for the first time set out the 
objectives of a common European development policy as part of an attempt to reduce inconsistencies between different policies (then Title XVII, Article 130u; after the entry into force of the Amsterdam Treaty, Title XX, Articles 179-81). The purpose is not to create a single development policy but rather to make the bilateral policies of the fifteen member states consistent and complementary with the common policy. Thus Article 130x reads: 'The Community and the member states shall coordinate their policies on development cooperation and shall consult each other on their aid programmes .... In theory this would provide a level playing field for the many partners with which the EU and its member states have agreements. However, practice is utterly different.

Within the internal workings of the EU the Commission is the chief initiator of policy and implementor of EU development policy, which falls mainly under the economic and commercial policies of the EU and also has Common Foreign and Security Policy (CFSP) aspects. Although only the Commission has the right to initiate policy, it is often viewed as the civil service of the member states. While the Commission seeks to expand its competencies, the Council often seeks to curtail Commission aspirations (Middlemas, 1995: 210-27). The result is that the Commission has been criticised for putting forward grandiose plans without the necessary capacity to deliver (Committee of Independent Experts Report, 1999). This has been compounded by staff problems, in terms of quality and numbers, in the sections relevant to traditional development cooperation.

The Commission is aware that development policy and other facets of Community policy are not always consistent (and referred to this as 'linkage shortfall') (CEC, 1992: 42). This is another issue which needs to be addressed if the Community is to increase its effectiveness in international development. The lack of cohesion between different policies, directorates and services means that while overall the Commission may have a formal commitment to the elimination of poverty in the South, sections within the Commission may have competing priorities. Although internal mechanisms for coordination exist they are not effective. The lack of consistency promotes the appearance of a confused, unfocused actor and has prompted calls for a single external relations Commissioner within a reformed Commission.

Nevertheless, there is a noticeable trend towards enlarging the scope of activities carried out at the Community level (Edwards and Regelsberger, 1990: 4). The Community now has relations with almost all developing countries. Some are with individual states, for example Cuba. Others are with regional organisations, for example the Association of South East Asian Nations (ASEAN) and Mercado Comun del Sur (MERCOSUR; the Southern common market). Yet others apply to groups of trans-regional states such as the ACP. 


\section{The impact of the end of the Cold War}

High expectations generated by the end of the Cold War led optimists to hope for a peace dividend: finance previously tied up in the arms race could now be used to help the poor, and aid would no longer be based on Cold War rivalries but on need. These hopes proved to be misplaced. While the end of the ideological and political division that dominated international relations, within and outside Europe, was a determining factor for many changes in development cooperation, it has not brought forth any significant additional aid to traditional recipients and political conditionality has only increased.

However, the end of the Cold War directly initiated a process of change in EU development cooperation. The changed geo-political situation that emerged during the 1990s had a profound impact on the European Union's external cooperation priorities. This was put straightforwardly in the April 2000 Commission document 'Communication on the European Community's Development Policy' (CEC, 2000a: 4):

Development policy is today one of the three principal components of the EU's external action, alongside trade policy and the political dimension. In addition to the objectives specific to development policy, other factors - such as geopolitics, trade, and global environmental problems - affect the EU's external choices. ... In this context, the EU's objective interests have led it to give priority to the stability and development of neighbouring countries and to aid for countries in crisis in the regions nearest to the EU.

Within the changed post-Cold War political constellation, the European Union caught sight of an unprecedently large group of 'new' countries in its immediate vicinity in need of assistance. Politically, and perhaps economically too, it had no choice but to approach them sympathetically. The reunification of Germany, the disintegration of the Soviet Union and the outbreak of largescale armed conflict in, and the falling apart of, the former Yugoslavia further increased the weight of intra-European problems on the EU's agenda. This took away space that previously was available for addressing development challenges in other parts of the world.

While overall apparently there is no hard evidence of shifts of development aid resources from the South to the East (Cox and Chapman, 1999: 76; Raffer, 1999), clear re-orientations have emerged in aid allocation patterns. As a direct result of the changing interests and priorities, the traditional developing country cooperation partners of the European Union, notably the ACP countries, have lost out significantly on their previously largely unchallenged share of structural European Community development aid. For example, the share of sub-Saharan Africa in total allocable EC aid has gone down from 70 per cent at the beginning of the 1970 s, to 60 per cent at the beginning of the 1980s, to some 30 per cent over 1996-97. In contrast, during the period 1990-97, the Central and Eastern European countries and the new inde- 
pendent states of the former Soviet Union built up a share of 19 per cent of allocable Community aid. This trend had begun by the start of the Phare programme in 1990 and rapidly extended thereafter. The Middle East's and nonEU southern European's share in total allocable EC aid doubled from 6 per cent in the 1970s and 1980s to 14 per cent over 1996-97 (Cox and Chapman, 1999: 2 and $101 \mathrm{ff}$.).

Another major change that occurred in the 1990s relates to the issue of political conditionality of Community development assistance. The end of the Cold War brought about changes in the tone and orientation of global and inter-regional debates on human rights and development. A slightly more open climate emerged for addressing issues in this realm. Controversy over the interrelationship between human rights, development and democratisation gradually reduced somewhat, although it certainly did not disappear (Arts, 2000: e.g. 28-31 and 110-11). Accordingly, from the early 1990s, human rights, democracy, and later also governance considerations, became increasingly important determinants in the European Union's external relations as a whole.

The November 1991 Council of Ministers 'Resolution on human rights, democracy and development' set the main agenda to be pursued through European Community development cooperation and the basic approaches through which this was to be done (Council of Ministers, 1991). Thereafter, the Community, at a breathtaking pace, formulated a large number of specific human rights and governance-related conditions and criteria for its development assistance. Many of these were developed through jointly negotiated clauses in newly concluded cooperation treaties, including the Lomé IV and Lomé IV-bis Conventions, and the Europe Agreements. However, the Community did not hesitate to introduce and specify additional conditionalities unilaterally. At least three means were used for this purpose. Firstly, the various Community Regulations that set the legal framework for development cooperation gradually came to include specific references and procedures for taking up human rights and democracy concerns. Examples include the regulations on financial and technical assistance to developing countries in Asia and Latin America (ALA), and on the Generalised System of Preferences (GSP). Secondly, throughout the 1990s a regular stream of Council of Ministers' resolutions and Commission documents defined the Community's understanding of certain human rights-related terms and concepts, or further specified Community priorities and criteria (Arts, 2000: 118-26 and 134-6). Thirdly, more and more often during the 1990s the Community resorted to the application of sanctions against developing countries that it deemed to have disrespected human rights, democracy or governance norms.

Particularly on the latter aspect - that is, in its human rights-related sanctions practice - the European Community regularly pushed matters too far, even up to the extent of violating international law. For example, the early practice of suspending the Lomé Convention because of alleged disrespect for 
human rights or democracy (i.e. at least until Lomé IV of 1989, the main text of which contained an elaborate human rights provision), and the more recent such punitive practice in response to 'bad' governance, amounted to straightforward violations of relevant international law (Arts, 2000: 193-200 and $321-48)$. This position is based on the fact that the international law norms governing the integration of human rights and democracy considerations into development cooperation are relatively clear and enjoy solid legal definition and status. Good governance, on the other hand, lacks international legal definition and is perhaps not an international legal principle at all (Arts, 2000: 40-1 and 50). Rather than drawing conclusions from this situation and changing its policy to a less pushy one on governance aspects, the Community has now engaged in strong efforts to legalise its unlawful practice by attempting to incorporate detailed good governance provisions in newly negotiated cooperation agreements. A controversial example is the set of good governance and corruption provisions in the Cotonou Agreement. Its Article 9(3) qualifies good governance as a 'fundamental element' of the Cotonou Agreement and defines it as:

the transparent and accountable management of human, natural, economic and financial resources for the purposes of equitable and sustainable development. It entails clear decision-making procedures at the level of public authorities, transparent and accountable institutions, the primacy of law in the management and distribution of resources and capacity building for elaborating and implementing measures aiming in particular at preventing and combating corruption. (Partnership Agreement, 2000)

Despite this broad definition, the enforcement mechanism for the good governance standard is strictly confined to the element of corruption. In case of 'serious cases of corruption', and when the Community is 'a significant partner in terms of financial support to economic and sectoral policies and programmes', 'appropriate measures' may be taken after having exhausted a prescribed consultation procedure (Partnership Agreement, 2000: Article 97). Basically the Community forced its most recent political priority through, and was not open to ACP opposition on this point. This appears clearly from the respective public statements made by both sides after the negotiations had finished. According to the Community, proudly, the newly agreed procedure is:

a real innovation, both in the EU-ACP context and in international relations. This procedure will be applied not only in cases of corruption involving [European Development Fund] EDF money but also more widely, in any country where the EC is financially involved and where corruption constitutes an obstacle to development. It is thus not confined to EC activities. . . . By adopting such a provision in their partnership agreement, the EU and the ACP States are together 
sending a clear and positive signal that will doubtlessly be appreciated by European taxpayers and investors, and by the legitimate beneficiaries of aid. (CEC, 2000b: 3-4)

The ACP, in an unusually strongly worded press release, expressed its dissatisfaction with the course of events and pointed at its attempts to amend the provisions concerned because it:

found them to be imbalanced as a result of the overemphasis given to EU objectives, particularly political objectives, while those of the ACP - such as development - were often ignored. Some attempt was made to remedy this criticism but the text is still unbalanced with EU objectives not only repeated ad nauseam but often elaborated whilst those of the ACP, such as the arms trade and the EU's role in this, do not merit a mention. (ACP Secretariat, 2000: 2; see also Dludlu, 2000)

The course of affairs concerning the elaboration of good governance provisions in the Cotonou Agreement clearly reveals the European Community's determination to create new ways and means for it to intensify this element of political conditionality. This is likely to be extended further in the future.

\section{Determinants of EU development cooperation policy}

The assumption of this book is that there are a number of causal factors in the disappearance of a unique European development policy, which was regularly referred to as a positive model for such a policy. These factors can be found in the internal workings of the European machinery as well as in external circumstances. Very often it is the interplay of the two which brings about shifts in the direction and content of development policy. Chapters 2 to 5 substantiate the position that EU development cooperation lost its uniqueness due to a variety of external explanatory factors.

Chapter 2, by William Brown, focuses on the influence of the World Bank on EU development cooperation policy, with special emphasis on the Lomé Convention. In particular, the chapter explores the extent to which EU policy has followed rather than diverged from that of the World Bank. It shows that the European Union has changed its Lomé policy gradually, for example by including structural adjustment issues and tightening political conditionality of aid. There are strong indications that these changes, which have caused a major and principled shift in the terms underlying ACP-EU cooperation, were instigated by World Bank ideas and practice. Thereby, the Union has compromised its own distinct policy-making identity.

Chapter 3, by Anna K. Dickson, explains the influence of trade liberalisation on EU trade preferences. It seeks to identify the main determinants of EU trade policy in relation to the developing countries. Whereas in 1975 the EU was prepared to challenge the prevailing liberal consensus and sign an inno- 
vative trade chapter with the ACP, by the 1990s this was no longer the case. The chapter asks what factors drove the EU decision to liberalise existing trade preferences. The working hypothesis was that the EU committed itself to trade liberalisation in part because the international climate for development cooperation has changed significantly so that preferential agreements are increasingly difficult to justify. In addition, external pressures - for example to reform the Common Agricultural Policy (CAP) - have implications for the trade preferences that the Union can offer to developing countries. The chapter assesses the manner in which the Commission has been influenced by the ideology of global trade liberalisation, and more recently its incarnation in the WTO, and the substantive political interests at stake in reforming the CAP. Specific reference is made to the Banana Protocol of the Lomé Convention, as an example of the EU's waning interest in preferential trade facilities.

Karen Smith, in chapter 4, provides a comparative analysis of the content and direction of the policies developed towards the ACP, the Mediterranean, Asia, Latin America and Eastern Europe. She examines the evolution and content of EU relations with these areas. She argues that the periphery of the European Union has become increasingly important to it. Relations with the traditional developing country partners, such as the ACP, are in the process of being 'normalised' and are beginning to look much more similar to relations with other regions. The signalled changes will be explained through a framework considering internal and external demands for EU action and involvement, the EU's sense of responsibility, economic interest, security considerations and others.

Chapter 5 by Gorm Rye Olsen shows how relevant European concerns have changed from development to security and complex political emergencies. This chapter argues that the developing world in general, and Africa in particular, are symbolic in the context of the European Union's efforts to become a more prominent international player. Since the end of the Cold War and the start of Lomé IV one can identify a change in the EU's external priorities, especially concerning sub-Saharan Africa. The EU has become more concerned with security issues, as reflected in the French-British plans to establish a special African intervention force supported and financed by the Union, and in the overall attention for conflict prevention and crisis management in Africa. The focus on security is partly a reflection of the growth in the number of so-called complex political emergencies which are caused by conflicts and civil wars. The mass media tend to focus on such dramatic events, which has strengthened the tendency in the EU to allocate more money to emergency operations. This put additional pressure on European aid budgets, already threatened by a combination of aid fatigue and a lack of vision for European aid. Also, it strengthened the prospects for stronger linkages between the CFSP and development cooperation policy.

Chapters 6 to 8 provide insight into some significant internal factors that help to explain the changes in EU development cooperation as they occurred 
over time, particularly since 1990. Karin Arts, in chapter 6, discusses the influence of changing EU membership and of advancing European integration. She first explores the effect on EU development policy of the changing EU membership. The chapter investigates the consequences of the accession of, respectively, the UK, Spain, Portugal, Sweden, Finland and Austria, and the (to be expected) further enlargement of the Union within the next decade, on the geographical scope of, and political priority for, development policy. The chapter then looks into the impact of the ever advancing process of European integration. It explores the impact of current efforts to strengthen the Union's external identity, of new Constituent Treaty mandates, the drive for consistency, and the trend to enhance the Union's accountability, transparency and efficiency. The chapter argues that, as a result of the internal determinants explored in it, the Union's interest in development cooperation with the South has clearly been diluted.

Chapter 7 by Anne-Sophie Claeys analyses the role of France and French interests in EU development policy since 1957. Since 1957, France has been heavily involved in the definition and implementation of European development policy. It has always considered this policy as a way to maintain French interests and influence over Africa, while sharing the costs of such a policy with EU member states. Claeys presents the channels used by France to influence the shaping of EU development policy. She examines the French interests and determinants for exerting such influence. France is now in the process of rethinking its approach, and is reducing its involvement in Africa. This has come about as a result of the end of the Cold War, economic concerns and new priorities in the sphere of security and proximity issues. The French Africa policy is thus in the process of 'normalisation', which in turn might have significant consequences for the European Union's policy.

Chapter 8, by Adrian Hewitt and Kaye Whiteman, looks into the bureaucratic politics of EU aid. Their chapter analyses the role of the Commission in the making of EU development policy. While the EU and the member states together are the largest donor, the impact of EU aid has been insignificant. Some reasons for this can be found in the bureaucratic politics of EU aid. These include issues such as division within and between the various relevant Commission Directorates; staffing; the role of individual Commissioners; and the influence of national governments through their experts.

Chapter 9, the final chapter, looks forward at the progress and changes made to EU development policy since the book was first conceptualised. Thus far, these changes indicate that the trends identified in the book have continued.

\section{Concluding remarks}

Development cooperation remains an important component of the EU's external relations policy. Nearly five decades of Community development coopera- 
tion have transformed the initial and tentative steps enshrined in the Rome Treaty into a collection of agreements, declarations of intent and actual policies. There is now a dedicated Commission that steers most, if not all, policy concerned with development. Issues of development concern numerous committees, delegations and, governmental and non-governmental organisations (NGOs), within the EU as well as in its constituent member states. Although the Lomé Conventions/Cotonou Agreement have not been widely heard of outside the EU/ACP context, they have arguably transformed the external dimension of EU and ACP relations.

The Lomé Convention has also engendered an institutional dialogue between North and South that is unparalleled in the field. That this dialogue has often been unsatisfactory should not detract from the precedent it set. From Europe's point of view the dialogue is significant because it links Europe with a large number of developing countries and boosts its image in the Third World and beyond. It has been particularly important to France and, to a lesser extent, to the UK. Despite its shortcomings, accession to the Convention was aspired to by many developing countries including, most recently, South Africa and Cuba.

However, in all of these spheres of activity, in the end the EU falls short. Whether it be the duplication of tasks by different member states, the contradictions and inconsistencies between policies created by different commissions, or the lack of a real dialogue between partners, the sum effect is the creation of an ineffective, and perhaps symbolic, development policy. That is to say, ineffective in the realm of producing, encouraging or facilitating development, although effective in creating the image of an actor engaged with the world's poor. The EU is aware of this criticism and has sought to remedy it through reform of the Commission and the decision-making structures of the EU, as well as undergoing a thorough rethinking of the methods by which it seeks to encourage development.

The parameters of the new situation have not yet been firmly decided. The ongoing process of enlargement and external events will challenge the Community's ability to effect the choices it makes as well as limit the options available. The analysis contained in the following chapters identifies and assesses trends in overall patterns of development policy since 1957. While largely critical of emerging trends, it does not preclude the possibility of a less symbolic, more substantive development policy for the future.

\section{Bibliography}

ACP Secretariat (2000), 'Press release on the conclusion of the successor agreement to the Lomé Convention', www.acpsec.org/gb/press/037900_e.htm (accessed 23 May 2000), p. 2.

Arts, K. (2000), Integrating Human Rights into Development Cooperation: The Case of the Lomé Convention, The Hague/London/Boston: Kluwer Law International. 
Bretherton, C. and J. Vogler (1999), The European Union as a Global Actor, London: Routledge.

CEC (1992), 'Development Policy in the Run Up to 2000', SEC (92) 915 final, Brussels. CEC (1997), 'The Green Paper on Relations between the European Union and the ACP Countries on the Eve of the 21st Century', Brussels: CEC.

CEC (2000a), 'Communication on the European Community's Development Policy', COM (2000) 212 final, Brussels.

CEC (2000b), 'The new ACP-EU Agreement', http://europa.eu.int/comm/ development/ document/acp_eu_agreement_en.htm (accessed 20 April 2000).

Council of Ministers of the European Communities (1991), 'Resolution on human rights, democracy and development', Bulletin of the European Communities, 24:11, pp. 122-3.

Council of Ministers of the European Communities (1997), 'Open meeting of the General Affairs Council on the future of Lomé', Brussels, 10 November.

Cox, A. and J. Chapman (1999), The European Community External Cooperation Programmes. Policies, Management and Distribution, Brussels: European Commission.

Dickson, A. (1995), 'The EC and its associates: changing priorities', Politics, 15:3, pp. $147-52$.

Dickson, A. (2000), 'The demise of the Lomé Protocols: revising European development policy', European Foreign Affairs Review, 5:2, pp. 197-214.

Dludlu, J. (2000), 'Governance, immigration bedevil a new Lomé pact', Business Day, 2 February.

Edwards, G. and E. Regelsberger (eds) (1990), Europe's Global Links, New York: St. Martin's Press.

Faber, G. (1982), The European Community and Development Cooperation, Assen: Van Gorcum.

Grilli, E. (1993), The European Community and the Developing Countries, Cambridge: Cambridge University Press.

Groux, J. and P. Manin (1985), The European Communities in the International Order, Brussels: CEC.

Hill, C. (1993), 'The capability-expectations gap or conceptualising Europe's international role', Journal of Common Market Studies, 31:3, pp. 305-28.

Holland, M. (2002), The European Union and The Third World, Basingstoke: Palgrave.

Hurt, S. (2003), 'Co-operation and coercion? The Cotonou Agreement between the European Union and ACP states and the end of the Lomé Convention', Third World Quarterley, 24:1, pp. 161-76.

Lister, M. (1997), The European Union and the South, London: Routledge.

McQueen, M. (1998), 'ACP-EU trade cooperation after 2000: an assessment of reciprocal trade preferences', Journal of Modern African Studies, 36:4, pp. 66992.

Middlemas, K. (1995), Orchestrating Europe, London: Fontana.

Parfitt, T. (1996), 'The decline of Eurafrica? Lomé's mid term review', Review of African Political Economy, no. 67, pp. 53-66.

Partnership Agreement (2000) between the African, Caribbean and Pacific States of the one part, and the European Community and its Member States, of the other part, signed in Cotonou on 23 June, in The Courier, special issue, September.

Peterson, J. (1998), 'The European Union as a global actor', in J. Peterson and H. Sjursen A Common Foreign Policy for Europe, London: Routledge. 
Raffer, K. (1999), 'More conditions and less money: shifts of aid policies during the 1990s', European Development Policy Study Group, Discussion Paper no. 15, September, www.euforic.org/dsa/dp15.htm, section 2.

Watts, P. (1998), 'Losing Lomé: the potential impact of the Commission guidelines on the ACP non-least developed countries', Review of African Political Economy, no. 75, pp. 47-51.

White, B. (2001), Understanding European Foreign Policy, Basingstoke: Palgrave. 